\title{
Women's Empowerment and Nutritional Status of their Children: A Community-based Study from Villages of Bhaktapur District, Nepal
}

\author{
Shiwakoti R*, Devkota MD, Paudel R \\ Department of Community Medicine and Public Health, Maharajgunj Medical Campus, Institute of Medicine, Nepal
}

Copyright $\mathrm{O} 2017$ by authors, all rights reserved. Authors agree that this article remains permanently open access under the terms of the Creative Commons Attribution License 4.0 International License

\begin{abstract}
Under-nutrition is one of the leading causes of morbidity and mortality among children. Since women are often the primary caregivers, their empowerment can influence nutritional status of their children. The objective of the study was to assess relationship between women's empowerment and nutritional status of their children. A cross-sectional descriptive study was carried out in randomly selected five villages of Bhaktapur district. A total of 402 children aged six to 59 months were selected using systematic random sampling and their mothers were interviewed. Women's empowerment was assessed using composite index. Anthropometric measurements were obtained using height board and digital scale. Multivariate logistic analysis was carried out. The results show that among 402 mothers, 18 percent were low empowered whereas 27 percent were highly empowered. The prevalence of underweight, stunting and wasting of children was 13, 19 and 7 percent respectively. Low empowerment of women was found to be positively associated with underweight ( $\mathrm{AOR}=5.070 ; 95$ percent $\mathrm{CI}$ : 1.885-13.638), stunting ( $\mathrm{AOR}=3.031 ; 95$ percent $\mathrm{CI}: 1.281-7.141)$ and wasting (AOR $=10.056 ; 95$ percent $\mathrm{CI}: 1.127-89.693)$ of their children. Women with low empowerment had children that were more underweight, stunted and wasted. These results suggest that improving women empowerment could have a positive impact on nutritional status of their children.
\end{abstract}

Keywords Women's Empowerment, Under-nutrition of Children, Bhaktapur, Nepal

\section{Introduction}

Under-nutrition is one of the leading causes of morbidity and mortality among the under-five children. Globally, more than three million preventable child deaths can be attributed to child under-nutrition. A current estimate indicates that nearly 165 million under-five children are stunted, more than 100 million are underweight and 52 million are wasted (1). In Nepal 11 percent, 29 percent and 41 percent of the children are wasted, underweight and stunted respectively (2).

Under-five children are the vulnerable and the most important target group (3) where malnutrition plays a pivotal role in their mortality and morbidity along with delayed mental and motor development. In the long run, malnutrition decreases the educational achievement, labor productivity and economic growth of a country (4). Adequate nutrition during infancy and childhood is fundamental to a child's full developmental potential (5).

The various risk factors for child under-nutrition are identified, which are related to the child, mother and their environment $(6,7)$. Since women are often the primary caregivers, their empowerment can influence nutritional status of their children (8).

Although improvement in women's status is a key factor in child health, its relative importance is not clearly understood as many researchers use proxy indictors such as education, employment or wealth status. Women empowerment is contextual and multidimensional in nature; the association between women's empowerment and health outcomes might or might not follow the same patterns $(8,9)$. Hence, it is important to study these relationships in the local context. This study was an attempt to fill the information and knowledge gap in this area and potential use of it will be policy and program design to appropriately address child nutrition in a sustainable way through women's empowerment.

\section{Objectives}

\subsection{General Objective}

To assess relationship between women's empowerment and nutritional status of their children aged six to 59 months in selected villages of Bhaktapur District, Nepal 


\subsection{Specific Objectives}

1. To determine the nutritional status of children aged six to 59 months

2. To measure empowerment level of women's having children aged six to 59 months

3. To assess the relationship between women's empowerment and nutritional status of their children aged six to 59 months

\section{Materials and Methods}

\subsection{Study Area}

The study was conducted in Bhaktapur District, one of the districts of central developmental region of Nepal. It consists of 2 municipalities and 16 villages. It is adjacent to the capital city Kathmandu and is located in the eastern part of Kathmandu valley. It is growing in faster pace of modernization.

\subsection{Study Design and Selection of Participants}

Table 1. Calculation of sample size

\begin{tabular}{|c|c|c|c|c|c|}
\hline S.N. & Variables & $\begin{array}{c}\mathrm{p} \\
\text { (prevalence) }\end{array}$ & $\mathrm{N}_{\mathrm{O}}$ & $5 \%$ of $\mathrm{N}_{\mathrm{O}}$ & $\begin{array}{l}\mathrm{N}=\mathrm{N}_{\mathrm{O}}+ \\
5 \% \text { of } \mathrm{N}_{\mathrm{O}}\end{array}$ \\
\hline 1 & Stunting & $41 \%$ & 372 & 19 & 391 \\
\hline 2 & Wasting & $11 \%$ & 150 & 8 & 158 \\
\hline 3 & Under-weight & $29 \%$ & 316 & 16 & 332 \\
\hline 4 & $\begin{array}{c}\text { High } \\
\text { empowerment } \\
\text { level }\end{array}$ & $17 \%$ & 217 & 11 & 228 \\
\hline 5 & $\begin{array}{c}\text { Moderate } \\
\text { empowerment } \\
\text { level }\end{array}$ & $48 \%$ & 383 & 19 & 402 \\
\hline 6 & $\begin{array}{l}\text { Low empowerment } \\
\text { level }\end{array}$ & $35 \%$ & 349 & 17 & 366 \\
\hline
\end{tabular}

Note: Prevalence of the variables was taken from Nepal Demographic Health Survey (NDHS) 2011(2). Since the largest calculated sample size was 402 , it was taken as the sample size of the study.

A cross-sectional descriptive study was carried out in Bhaktapur District, Nepal. Out of 16 villages, five villages (Katunje, Gundu, Jhaukhel, Duwakot and Balkot) were randomly selected. The sample size i.e. 402 was calculated through the Epi-Info Statcalc version seven with 95 percent two-sided confidence level and five percent non-response rate (Table 1). Village level complete list of under-five children was prepared with the help of Vitamin A register maintained by Female Community Health Volunteers (FCHVs) of each selected wards and inquiry with FCHV for missing households from the register. The total number of children was 4673. From the sampling framework prepared, 402 samples were selected using systematic random sampling. The first sample was randomly selected from Katunje village and the subsequent sample was selected in the interval of 12 from the list. When mother had more than one child aged six to 59 months, the older child was excluded. Caretaker of the child other than mother was excluded. The dropout rate was zero.

\subsection{Data Collection and Statistical Analysis}

Table 2. Scoring of the five indicators used in the development of the Women's Empowerment Index:

\begin{tabular}{|c|c|c|}
\hline S.N. & Questions & Coding and scores \\
\hline & $\begin{array}{l}\text { Women's involvement in } \\
\text { household decision-making } \\
\text { (Include } 3 \text { decisions: access } \\
\text { to health care, household } \\
\text { purchasing, and freedom to } \\
\text { visit relatives) }\end{array}$ & $\begin{array}{c}\text { Participated in all } 3 \text { decisions } \\
=2 \\
\text { Participated in } 1 \text { or } 2 \\
\text { decisions }=1 \\
\text { Did not participate in any } \\
\text { decisions }=0\end{array}$ \\
\hline & $\begin{array}{l}\text { Women's membership in } \\
\text { community groups }\end{array}$ & $\begin{array}{l}\text { Member of any community } \\
\text { group (mothers' group, } \\
\text { saving group, women's } \\
\text { group }=1 \\
\text { Was not involved in any } \\
\text { groups }=0\end{array}$ \\
\hline & Women's cash earnings & $\begin{array}{l}\text { Earned cash only or both } \\
\text { cash and in-kind }=1 \\
\text { Did not earn cash at all }=0\end{array}$ \\
\hline & $\begin{array}{c}\text { Women's ownership of } \\
\text { house/land }\end{array}$ & $\begin{array}{l}\text { Owned a house, land, or both } \\
\text { alone or jointly with } \\
\text { husband }=1 \\
\text { Did not own any house, land } \\
=0\end{array}$ \\
\hline & Women's education & $\begin{array}{l}\text { Attained secondary or higher } \\
\text { education }=2 \\
\text { Attained primary level } \\
\text { education }=1 \\
\text { Did not attend school at all }=0\end{array}$ \\
\hline
\end{tabular}

Note:

The total scores $=0-7$

0 to $2=$ Low empowerment level

3 or $4=$ Moderately empowered

5 to $7=$ Highly empowered

Tools for data collection were Seca digital weighing scale, height board of UNICEF, stature meter and structured-questionnaire. Weighing equipment was standardized with standard weights before taking every measurement. The precision of the Seca digital weighing scale was $100 \mathrm{gm}$. The height was recorded to the nearest 0.1 $\mathrm{cm}$. The height was recorded after being checked by two persons. The weight was taken on barefoot and minimal cloths. For child less than 1 year of age, the "mother-and-baby function" was used that enabled determination of the body weight of child while being held in the arms of the mother. The height board and stature meter were used to measure length/height of children and height of mother respectively. Recumbent length in children younger than 24 months of age and standing height for 24 months onwards were measured. Z-score was used to determine underweight, stunting and wasting based on WHO Growth Standard-2006(10). Individual face-to-face interview of mothers having children aged 6-59 months was taken using pre-designed, pre-tested, structured questionnaire. NDHS questionnaires were adapted for measuring wealth index (11) and Women's Empowerment 
Index (12). Similarly, Household Food Insecurity Access Scale, developed by USAID's Food and Nutrition Technical Assistance project (13) was used for measuring household food insecurity. WHO criteria was followed for developing questionnaire on child feeding practices(14) with necessary modifications as appropriate to the local context.

Age of child was determined by asking mother about the current age of the child. It was crosschecked and ascertained from birth certificate, hospital discharge certificate, mother and child card or local calendar of events. The age of the child was calculated by subtracting date of birth from date of interview. The anthropometric measurement was carried out as per WHO guideline(15). Women's empowerment was assessed using Women's Empowerment Index (12), which composed of five variables; women's involvement in household decision-making, membership in community groups, cash earnings, ownership of house/land and education of women (Table 2).

Questionnaire was translated into Nepali language after consulting with experts and pretested in Dadhikot village of Bhaktapur District which constituted 10 percent of sample size. After pre-testing of the tools, some skipping pattern in questionnaire was added. However, the result of pre-test was not analyzed.

After pre-testing of questionnaire, researcher herself was involved in the data collection process with the support of four enumerators. It took total eight weeks for data collection from $16^{\text {th }}$ September 2014 to $15^{\text {th }}$ November 2014.

Coding and entry of collected data were done in Epidata 3.1. Anthropometric calculation was done in WHO Anthro version 3.2.2(16). Necessary cleaning of data such as detection and correction of inaccurate record, harmonization of short codes to actual words were done. Exclusion criteria were such as determined beforehand. All the collected data were complete thus none of the participants were excluded. Data was analyzed in Version 20 of Statistical Package for Social Sciences Software.

Descriptive analyses were conducted to present general information of the study population. Bivariate and multivariate analyses were done to find our association between outcome and explorative variables. In bivariate analysis, Chi-square test (or Fisher exact test) was applied to test the significance of association between independent and dependent variables. Odds ratio with 95 percent confidence interval (CI) interval was used to test the strength of the association. Variables that were found statistically significant at 90 percent $\mathrm{CI}$ during bivariate analysis were checked for multicollinearity and then further analyzed using logistic regression model in multivariate analysis. Adjusted Odds Ratio (AOR) with 95 CI and p-value were calculated.

\subsection{Variables}

Children whose Weight-for-Age Z-Score (WAZ) was below minus two standard deviations (-2 SD) from the median of the WHO reference population were classified as underweight. Children whose Height-for-Age Z-score (HAZ) was below -2 SD from the median of the WHO reference population were considered short for their age (stunted) or chronically malnourished. Children whose Weight-for-Height Z-score (WHZ) was below -2 SD from the median of the WHO reference population were considered thin (wasted) or acutely malnourished (17). Age of the child was calculated by subtracting date of birth from date of interview. Women's empowerment was assessed using Women's Empowerment Index (Table 1)(12). For socioeconomic status, wealth index was computed using Principle Component Analysis considering the assets holdings of participants. The components included in wealth index were ownership of house, vehicle, animals, electronic goods (radio, television, and refrigerator), furniture (table, chair, sofa, and cupboard), mobile phone, telephone, housing characteristics and type of fuel for cooking. The wealth quintiles (from lowest to highest) were ranked into five equal categories, each comprising 20 percent of the study population.

\subsection{Ethical Consideration}

The study was approved by the Institutional Review Board of Institute of Medicine, Tribhuwan University, Kathmandu, Nepal. Informed written consent was obtained from participants. Confidentiality of information was assured and insured throughout the study. Information on nutrition was given to mothers having undernourished children. Mothers of severely undernourished children were advised to seek health care from the nearest health facility or Kanti Children Hospital.

\section{Results}

Table 3 shows the general characteristics of the participants. Among 402 mothers and their children, the mean age of mothers was 27 years and the mean age of children was 27 months.

The prevalence of underweight, stunted and wasted among children were 13.4 percent (95 percent CI: $10.1,16.7)$, 19.4 percent (95 percent CI: $15.5,23.3)$ and 6.5 percent $(95$ percent CI: 4.1, 8.9) respectively. The mean Z-score for weight-for-age (underweight) was -0.82 (95 percent CI: -0. $917,-0.714)$, for length-for-age (stunting) was -1.08 (95 percent CI: $-1.201,-0.963)$ and for weight-for-length (wasting) was -0.32 (95 percent CI: $-0.421,-0.201$ ) (Table 4).

More than half (56 percent) of participant women were moderately empowered. About one in five (18 percent) were low empowered whereas about one in four ( 27 percent) were highly empowered (Table 5). 
Table 3. Distribution of demographic characteristics of the respondents

\begin{tabular}{|c|c|c|}
\hline Characteristics & Number $(\mathrm{n}=402)$ & Percent \\
\hline 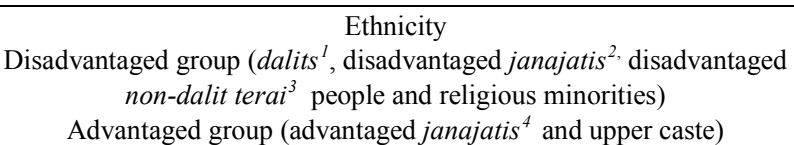 & $\begin{array}{l}88 \\
314\end{array}$ & $\begin{array}{l}21.9 \\
78.1\end{array}$ \\
\hline $\begin{array}{c}\text { Age group of mother (in years) } \\
<20 \\
20-34 \\
\geq 35 \\
\text { Mean age } \pm \mathrm{SD} \\
\end{array}$ & $\begin{array}{r}15 \\
357 \\
30 \\
27.22 \pm 4.60 \\
\end{array}$ & $\begin{array}{c}3.7 \\
88.8 \\
7.5\end{array}$ \\
\hline $\begin{array}{c}\text { Religion } \\
\text { Hindu } \\
\text { Other (Buddhist, Muslim, Christian) }\end{array}$ & $\begin{array}{c}381 \\
21\end{array}$ & $\begin{array}{c}94.8 \\
5.2 \\
\end{array}$ \\
\hline $\begin{array}{c}\text { Family size } \\
\leq 5 \text { persons } \\
>5 \text { persons } \\
\text { Mean household size } \pm \text { SD } \\
\end{array}$ & $\begin{aligned} & 252 \\
& 150 \\
& 5.71 \pm 4.05\end{aligned}$ & $\begin{array}{l}62.7 \\
37.3\end{array}$ \\
\hline $\begin{array}{c}\text { Type of family } \\
\text { Nuclear } \\
\text { Joint } \\
\text { Extended } \\
\end{array}$ & $\begin{array}{c}194 \\
170 \\
38 \\
\end{array}$ & $\begin{array}{c}48.3 \\
42.3 \\
9.5 \\
\end{array}$ \\
\hline $\begin{array}{l}\text { Number of children in family } \\
\text { Single child } \\
\text { Two or more child } \\
\end{array}$ & $\begin{array}{l}187 \\
215 \\
\end{array}$ & $\begin{array}{l}46.5 \\
53.5 \\
\end{array}$ \\
\hline $\begin{array}{c}\text { Age of index child (in months) } \\
6-11 \\
12-23 \\
24-35 \\
36-47 \\
48-59 \\
\text { Mean age } \pm \text { SD } \\
\end{array}$ & $\begin{array}{c}76 \\
112 \\
100 \\
66 \\
48 \\
26.87 \pm 14.68 \\
\end{array}$ & $\begin{array}{l}18.9 \\
27.9 \\
24.9 \\
16.4 \\
11.9\end{array}$ \\
\hline $\begin{array}{l}\text { Sex of index child } \\
\text { Male } \\
\text { Female }\end{array}$ & $\begin{array}{l}226 \\
176 \\
\end{array}$ & $\begin{array}{l}56.2 \\
43.8 \\
\end{array}$ \\
\hline $\begin{array}{c}\text { Birth order } \\
\text { First } \\
\text { Second } \\
\text { Third or more } \\
\end{array}$ & $\begin{array}{c}191 \\
166 \\
45 \\
\end{array}$ & $\begin{array}{l}47.5 \\
41.3 \\
11.2 \\
\end{array}$ \\
\hline $\begin{array}{l}\text { Birth interval in months }(\mathrm{n}=211) \\
\qquad 24 \\
25-47 \\
>47 \\
\text { Mean birth interval } \pm \mathrm{SD}\end{array}$ & $\begin{array}{c}34 \\
48 \\
129 \\
61.43 \pm 38.43\end{array}$ & $\begin{array}{l}16.1 \\
22.7 \\
61.7\end{array}$ \\
\hline
\end{tabular}

Table 4. Nutritional status of the children

\begin{tabular}{|c|c|c|}
\hline Characteristics & Number $(n=402)$ & Percent $(95 \% \mathrm{CI})$ \\
\hline $\begin{array}{c}\text { Underweight } \\
\text { Mean Z-score for weight-for-age }(95 \% \mathrm{CI})\end{array}$ & $\begin{array}{c}54 \\
-0.82(-0.917,-0.714) \\
\end{array}$ & $13.4(10.1,16.7)$ \\
\hline $\begin{array}{c}\text { Stunting } \\
\text { Mean Z-score for length-for-age }(95 \% \mathrm{CI})\end{array}$ & $\begin{array}{c}78 \\
-1.08(-1.201,-0.963) \\
\end{array}$ & $19.4(15.5,23.3)$ \\
\hline $\begin{array}{c}\text { Wasting } \\
\text { Mean Z-score for weight-for-length }(95 \% \mathrm{CI})\end{array}$ & $\begin{array}{c}26 \\
-0.32(-0.421,-0.201)\end{array}$ & $6.5(4.1,8.9)$ \\
\hline
\end{tabular}


Table 5. Women empowerment index and its various dimensions

\begin{tabular}{ccc}
\hline Characteristics & Number $(\mathrm{n}=402)$ & Percent $(95 \% \mathrm{CI})$ \\
\hline Low & 72 & $17.9(14.2,21.6)$ \\
Moderate & 223 & $55.5(50.6,60.4)$ \\
High & 107 & $26.6(16.6,30.9)$ \\
\hline Participation in three key household decision-making & & 18.2 \\
No participation & 73 & 30.1 \\
Participate in one or two decisions & 121 & 51.7 \\
Participate in all three decisions & 208 & \\
Membership in community group & & 67.9 \\
No & 273 & 32.1 \\
Yes & 129 & 68.2 \\
Earning status & & 31.8 \\
No & 274 & \\
Yes & 128 & 92.8 \\
No & 373 & 7.2 \\
\hline Yes & 29 & 8.7 \\
Ownership of house/land & 35 & 17.4 \\
No education & 70 & 21.1 \\
Primary level & 85 & 52.7 \\
\hline Some secondary level & 212 & \\
\hline
\end{tabular}

Bivariate analysis showed that five factors i.e. age of child, wealth quintile, separate kitchen, Body Mass Index (BMI) of mother, women's empowerment were independently associated with underweight of children (Table 6). Six factors (Age of child, place of delivery, number of growth monitoring in the last six months, treatment of drinking water, separate kitchen, women's empowerment) were independently associated with stunting (Table 7). Two factors (Colostrum feeding and women's empowerment) were independently associated with wasting (Table 8).

Table 6. Unadjusted and adjusted OR and 95 percent CI for effect of women's empowerment on underweight of children ( $\mathrm{n}=402)$

\begin{tabular}{|c|c|c|c|}
\hline Characteristics & Unadjusted OR (95 \% CI) & Adjusted OR without WEI $(95 \%$ CI $)$ & Full model OR $(95 \% \mathrm{CI})$ \\
\hline \multicolumn{4}{|c|}{ Women Empowerment Index (WEI) } \\
\hline Low & $6.286(2.516-15.706)^{*}$ & & $5.070(1.885-13.638)^{*}$ \\
\hline Moderate & $1.804(0.754-4.314)$ & & $1.596(0.650-3.916)$ \\
\hline High & Ref & & Ref \\
\hline \multicolumn{4}{|l|}{ Age of index child } \\
\hline$\geq 24$ months & $1.910(1.045-3.493)^{*}$ & $2.287(1.207-4.335)^{*}$ & $2.345(1.215-4.524)^{*}$ \\
\hline$<24$ months & Ref & Ref & Ref \\
\hline \multicolumn{4}{|l|}{ Type of family } \\
\hline Joint and extended & $0.599(0.335-1.072)$ & $0.791(0.415-1.508)$ & $0.658(0.338-1.279)$ \\
\hline Nuclear & Ref & Ref & Ref \\
\hline \multicolumn{4}{|l|}{ Wealth quintile } \\
\hline Lowest & $6.926(1.942-24.705)^{*}$ & $6.048(1.627-22.481)^{*}$ & $4.555(1.190-17.445)^{*}$ \\
\hline Second & $3.208(0.835-12.321)$ & $2.657(0.642-10.999)$ & $2.239(0.527-9.519)$ \\
\hline Middle & $5.923(1.642-21.363)$ & $4.580(1.131-18.549)$ & $2.943(0.703-12.330)$ \\
\hline Fourth & $3.615(0.956-13.667)$ & $3.003(0.762-11.843)$ & $2.980(0.748-11.882)$ \\
\hline Highest & Ref & Ref & Ref \\
\hline \multicolumn{4}{|l|}{ Separate kitchen } \\
\hline No & $1.878(1.026-3.439)^{*}$ & $1.253(0.600-2.617)$ & $1.081(0.512-2.280)$ \\
\hline Yes & Ref & Ref & Ref \\
\hline \multicolumn{4}{|l|}{ BMI of mother } \\
\hline Underweight & $1.602(0.645-3.980)$ & $1.780(0.668-4.741)$ & $1.731(0.634-4.472)$ \\
\hline Overweight & $0.417(0.179-0.971)^{*}$ & $0.448(0.187-1.072)$ & $0.476(0.195-1.164)$ \\
\hline Obese & $1.090(0.353-3.362)$ & $1.217(0.372-3.976)$ & $1.144(0.331-3.956)$ \\
\hline Normal & Ref & Ref & Ref \\
\hline
\end{tabular}

* Significant at $\mathrm{p}<0.05 ;$ Ref $=$ Reference category 
Table 7. Unadjusted and adjusted OR and 95 percent CI for effect of women's empowerment on stunting of children ( $\mathrm{n}=402)$

\begin{tabular}{|c|c|c|c|}
\hline Characteristics & Unadjusted OR (95 \% CI) & Adjusted OR without WEI (95 \% CI) & Full model $(95 \% \mathrm{CI})$ \\
\hline \multicolumn{4}{|c|}{ Women empowerment index } \\
\hline Low & $3.615(1.692-7.725)^{*}$ & & $3.031(1.287-7.141)^{*}$ \\
\hline Moderate & $1.629(0.832-3.189)$ & & $1.413(0.697-2.862)$ \\
\hline High & Ref & & Ref \\
\hline \multicolumn{4}{|l|}{ Age of index child } \\
\hline$\geq 24$ months & $2.482(1.456-4.230)^{*}$ & $2.463(1.359-4.465)^{*}$ & $2.514(1.375-4.595)^{*}$ \\
\hline$<24$ months & Ref & Ref & Ref \\
\hline \multicolumn{4}{|l|}{ Wealth quintile } \\
\hline Lowest & $1.189(0.525-2.693)$ & $0.893(0.366-2.178)$ & $0.733(0.292-1.839)$ \\
\hline Second & $0.896(0.382-2.105)$ & $0.615(0.229-1.653)$ & $0.563(0.207-1.529)$ \\
\hline Middle & $1.955(0.925-4.224)$ & $0.926(0.338-2.539)$ & $0.761(0.273-2.125)$ \\
\hline Fourth & $1.269(0.566-2.845)$ & $1.292(0.553-3.018)$ & $1.299(0.553-3.049)$ \\
\hline Highest & Ref & Ref & Ref \\
\hline \multicolumn{4}{|l|}{ Place of delivery } \\
\hline Elsewhere & $2.100(1.076-4.096)^{*}$ & $1.455(0.676-3.132)$ & $1.322(0.601-2.905)$ \\
\hline Health facility & Ref & Ref & Ref \\
\hline \multicolumn{4}{|c|}{ Number of growth monitoring in the last six months } \\
\hline$\leq 2$ times & $0.408(0.219-0.761)^{*}$ & $1.850(0.937-3.650)$ & $1.811(0.911-3.602)$ \\
\hline$>2$ times & Ref & Ref & Ref \\
\hline \multicolumn{4}{|c|}{ Treatment of drinking water } \\
\hline No & $1.743(1.011-3.006)^{*}$ & $1.484(0.768-2.867)$ & $1.331(0.679-2.608)$ \\
\hline Yes & Ref & Ref & Ref \\
\hline \multicolumn{4}{|l|}{ Separate kitchen } \\
\hline No & $2.309(1.367-3.897)^{*}$ & $2.398(1.229-4.680) *$ & $2.313(1.179-4.540)^{*}$ \\
\hline Yes & Ref & Ref & Ref \\
\hline \multicolumn{4}{|l|}{ BMI of mother } \\
\hline Underweight & $1.541(0.671-3.542)$ & $1.738(0.696-4.336)$ & $1.629(0.646-4.111)$ \\
\hline Overweight & $0.891(0.495-1.605)$ & $0.905(0.483-1.696)$ & $0.966(0.510-1.830)$ \\
\hline Obese & $0.164(0.022-1.243)$ & $0.175(0.022-1.366)$ & $0.166(0.021-1.319)$ \\
\hline Normal & Ref & Ref & Ref \\
\hline
\end{tabular}

* Significant at $\mathrm{p}<0.05$

Ref $=$ Reference category

Table 8. Unadjusted and adjusted OR and 95 percent CI for effect of women's empowerment on wasting of children ( $\mathrm{n}=402)$

\begin{tabular}{|c|c|c|c|}
\hline Characteristics & $\begin{array}{c}\text { Unadjusted OR } \\
(95 \% \mathrm{CI}) \\
\end{array}$ & $\begin{array}{l}\text { Adjusted OR without WEI } \\
(95 \% \mathrm{CI})\end{array}$ & Full model Adjusted OR $(95 \% \mathrm{CI})$ \\
\hline \multicolumn{4}{|l|}{ Women empowerment index } \\
\hline Low & $17.097(2.137-136.765)^{*}$ & & $10.056(1.127-89.693)^{*}$ \\
\hline Moderate & $7.644(0.996-58.654)$ & & $5.318(0.657-43.029)$ \\
\hline High & Ref & & Ref \\
\hline \multicolumn{4}{|l|}{ Occupation of mother } \\
\hline Homemaker & $2.805(0.946-8.315)$ & $2.694(0.893-8.124)$ & $1.708(0.536-5.442)$ \\
\hline Other than homemaker & Ref & Ref & Ref \\
\hline \multicolumn{4}{|l|}{ Wealth quintile } \\
\hline Lowest & $4.333(0.891-21.086)$ & $4.185(0.832-21.061)$ & $3.245(0.635-16.587)$ \\
\hline Second & $2.026(0.360-11.386)$ & $1.529(0.262-8.935)$ & $1.258(0.211-7.493)$ \\
\hline Middle & $3.740(0.752-18.589)$ & $3.228(0.618-16.484)$ & $2.076(0.371-11.624)$ \\
\hline Fourth & $2.566(0.483-13.630)$ & $2.195(0.398-12.118)$ & $2.186(0.394-12.118)$ \\
\hline Highest & Ref & Ref & Ref \\
\hline \multicolumn{4}{|l|}{ Colostrum feeding } \\
\hline No & $3.184(1.259-8.051)^{*}$ & $3.734(1.400-9.961)^{*}$ & $3.438(1.278-9.253)^{*}$ \\
\hline Yes & Ref & Ref & Ref \\
\hline \multicolumn{4}{|l|}{ BMI of mother } \\
\hline Underweight & $0.782(0.174-3.528)$ & $0.726(0.157-3.357)$ & $0.662(0.141-3.105)$ \\
\hline Overweight & $0.352(0.102-1.217)$ & $0.346(0.096-1.249)$ & $0.378(0.103-1.390)$ \\
\hline Obese & $1.021(0.223-4.661)$ & $1.203(0.250-5.782)$ & $1.226(0.245-6.149)$ \\
\hline Normal & Ref & Ref & Ref \\
\hline
\end{tabular}

* Significant at $\mathrm{p}<0.05$

Ref $=$ Reference category 
Those variables that exhibited significant association with under nutrition of children at 90 percent CI during bivariate analysis were further subjected to multivariate logistic regression. Multicollinearity test was done. None of them have tolerance $<0.1$ and Variance Inflation Factor (VIF) $>10$. There was no problem of collinearity among independent variables as the highest VIF for underweight, stunting and wasting were $1.228,1.169$ and 1.199 respectively.

The result shows that in comparison to highly empowered mothers, low empowered mothers were five times (Adjusted $\mathrm{OR}=5.070$; 95 percent CI: 1.885-13.638) (Table 5), three times (Adjusted $\mathrm{OR}=3.031$; 95 percent $\mathrm{CI}$ : 1.281-7.141) (Table 6) and ten times (Adjusted $\mathrm{OR}=10.056$; 95 percent CI: $1.127-89.693$ ) (Table 7) more likely to have underweight, stunted and wasted children respectively.

\section{Discussion}

The study showed that 19.4 (95 percent CI: $15.5,23.3$ ) percent of children aged six to 59 months were stunted. It is lower than national level i.e.41 percent but close to urban area i.e. 26.7 percent (2). This may be due to proximity of the study area, Bhaktapur to capital city Kathmandu. The variation may also be due to difference in age groups. NDHS calculated stunting among under-five children while this study included only children from six to 59 months.

The study showed that low level of empowerment was positively associated with under-nutrition of children; underweight (Adjusted $\mathrm{OR}=5.070 ; 95$ percent $\mathrm{CI}$ : 1.885-13.638), stunting (Adjusted $\mathrm{OR}=3.031$; 95 percent $\mathrm{CI}$ : 1.281-7.141) and wasting (Adjusted $\mathrm{OR}=10.056$; 95 percent CI: 1.127-89.693). These findings of the study are consistent with another study from Nepal, which found that women's empowerment was inversely related to anemia in children. Women at the low empowerment level had 1.8 times greater adjusted odds of having children with anemia than women at the high empowerment level (12).

In this study, higher mother's empowerment level which included decision-making was negatively associated with child under-nutrition which is consistent with the studies from Andhra Pradesh, India (18) and Afghanistan (19).A cross-sectional study conducted in Andhra Pradesh in rural India found that the ability to make household decisions was positively associated with child WAZ (AOR $=0.17 ; 95$ percent CI: 0.04.0.30) and $\mathrm{WHZ}(\mathrm{AOR}=0.26$; 95 percent $\mathrm{CI}$ : $0.16,0.42)(18)$. Likewise a study from Afghanistan found that a lack of maternal decision-making autonomy regarding obtaining health care for her children was positively associated with child underweight (AOR 1.46; 95 percent $\mathrm{CI}$ : -1.00, 2.14), stunting (AOR=1.38; 95 percent $\mathrm{CI}$ : - 1.01, 1.90) and wasting ( $\mathrm{AOR}=1.67 ; 95$ percent $\mathrm{CI}$ : - 1.00, 2.81) (19).

In this study, women empowerment that included involvement of women in household decision-making was statistically significant with nutritional status of children. It is consistent with a study from Karnataka (rural), which found maternal position within the household and involvement in decision making to be protective for child WAZ $(\mathrm{AOR}=-0.12 ; 9 ;-3.70)(9)$. By contrast, analysis of Bangladesh Demographic and Health Survey data did not reveal any statistically significant association between aggregated decision-making autonomy score (which combined autonomy regarding her own health care, child health care, large household purchases, daily household purchases and her freedom to visit relatives and friends) with underweight, stunting and wasting(20). The variation may be due to contextually of women's empowerment. In this study composite index of empowerment was used while the study from Bangladesh used only decision-making autonomy score.

The study showed that higher women's empowerment level, which included mother's membership in community group, was negatively associated with child undernutrition. The result is consistent with a cross-sectional study from Andra Pradesh, which found larger social network $(\mathrm{AOR}=0.21)$ and more literate social networks $(\mathrm{AOR}=0.56)$ to be associated with better Length-for-Age (LAZ) of 1-year-old children.(21) Another study from India found that high maternal cognitive social capital was associated with highest WAZ (Adjusted OR=0.19, CI: 0.00-0.39)(22).

In this study, higher women's empowerment level that included cash earning was negatively associated with child under-nutrition. The finding is consistent with study from study rural Karnataka, that showed a negative association between maternal employment and underweight in children aged 6-24 months of age ( $\mathrm{AOR}=-0.12)(9)$.

In this study ownership of house and land that comprise part of women's empowerment, was negatively associated with child under-nutrition. The finding is consistent with study from Nepal which found that women who own land are significantly more likely to have the final say in household decisions $(\mathrm{OR}=1.48)$, a measure of empowerment. Similarly, children of mothers who own land are significantly less likely to be severely underweight $(\mathrm{AOR}=0.54)(23)$. On the other hand a study from Uganda found that land ownership exhibited no differentials with child stunting (24).

In this study, higher women's empowerment level that included level of education was negatively associated with child under-nutrition. The finding is consistent with study from Bolivia that found that maternal education is negatively associated with stunting of children $(\mathrm{AOR}=-0.197$, Standard Error: 0.050)(25).

Since none of the available literature has used composite index of women empowerment, it is difficult to compare. However, the association between different domain of women's empowerment and child nutrition did not follow the same patterns in different countries studied.

This study is among a few studies conducted, which analyzed women's empowerment level using composite index and assessed association between women's empowerment and nutritional status of their children. However, this is not a nationally representative study, therefore cannot be generalized specially for rural setting 


\section{Conclusions}

The study showed strong association between women's empowerment and nutrition status of their children even after adjusting for numerous demographic covariates. There was a five-fold increase in odds of underweight, a three-fold increase in odds of stunting, and a ten-fold increase in odds of wasting among children whose mothers had low empowerment status compared to high empowerment status.

\section{Acknowledgements}

We are very grateful to the Department of Community Medicine and Public Health, Maharajgunj Medical Campus, Institute of Medicine for providing their continued guidance, supervision and encouragement throughout the process of this study. We would like to thank all women and their children who participated in the study.

\section{REFERENCES}

[1] Black RE, Victora CG, Walker SP, Bhutta ZA, Christian P, De Onis $M$, et al. Maternal and child undernutrition and overweight in low-income and middle-income countries. The Lancet. 2013; 382(9890):427-51.

[2] Mebrahtu S, Crum J, Dahal P, Pokharel R, Mason J, Hutchinson P. Trends and Determinants of Maternal and Child Under-nutrition in Nepal: Further Analysis of the Nepal Demographic Health Survey, 1996-2011. Annals of nutrition and metabolism: Karger Schwilerstrasse 10, Ch-4009 Basel, Switzerland 2013. p. 9-13.

[3] Rao VG, Yadav R, Dolla CK, Kumar S, Bhondeley MK, Ukey M. Undernutrition \& childhood morbidities among tribal preschool children. Indian journal of Medical research. $2005 ; 122(1): 43$.

[4] Alderman H, Hoddinott J, Kinsey B. Long term consequences of early childhood malnutrition. Oxford economic papers. 2006;58(3):450-74.

[5] Black RE, Allen LH, Bhutta ZA, Caulfield LE, De Onis M, Ezzati M, et al. Maternal and child undernutrition: global and regional exposures and health consequences. The lancet. 2008; 371(9608):243-60.

[6] Dasgupta A, Parthasarathi R, Biswas R, Geethanjali A. Assessment of Under Nutrition with Composite Index of Anthropometric Failure (CIAF) Among Under-Five Children in a Rural Area of West Bengal. Indian Journal of Community Health. 2014; 26(2):132-8.

[7] UNICEF. Improving child nutrition: The achievable imperative for global progress: United Nations Children's Fund; 2013.

[8] Bhagowalia P, Menon P, Quisumbing AR, Vidhya Soundararajan J. What dimensions of women's empowerment matter most for child nutrition. Evidence using national representative data from Bangladesh. 2012:1-16.
[9] Sethuraman K, Lansdown R, Sullivan K. Women's empowerment and domestic violence: the role of sociocultural determinants in maternal and child undernutrition in tribal and rural communities in South India. Food and nutrition bulletin. 2006; 27(2):128-43.

[10] Onis M. WHO Child Growth Standards based on length/height, weight and age. Acta paediatrica. 2006; 95(S450):76-85.

[11] Ministry of Health and Population (MoHP) N. Nepal Demogaphic Health Survey 2011. Kathmandu, Nepal: Ministry of Health and Population, New ERA, and ICF International, Calverton, Maryland; 2012. p. 25-180.

[12] Tuladhar S, Khanal KR, Lila KC, Ghimire PK, Onta K. Women's empowerment and spousal violence in relation to health outcomes in Nepal: Further analysis of the 2011 Nepal Demographic and Health Survey. 2013:2-39.

[13] Coates Jennifer SAB. Household Food Insecurity Scale (HFIAS) for Measurement of Food Access: Indicators Guideline. 2007:32.

[14] WHO. Indicators for assessing infant and young child feeding practices: part 2: measurement. 2010:24-43.

[15] De Onis M, Onyango AW, Van den Broeck J, Chumlea WC, Martorell R. Measurement and standardization protocols for anthropometry used in the construction of a new international growth reference. Food and nutrition bulletin. 2004; 25(1 Suppl): S27-36.

[16] Mbuh JV, Nembu NE. Malnutrition and intestinal helminth infections in schoolchildren from Dibanda, Cameroon. Journal of helminthology. 2013; 87(1):46-51.

[17] Braitstein P, Ayaya S, Nyandiko WM, Kamanda A, Koech J, Gisore P, et al. Nutritional status of orphaned and separated children and adolescents living in community and institutional environments in uasin gishu county, kenya. PloS one. $2013 ; 8(7)$ :e70054.

[18] Shroff MR, Griffiths PL, Suchindran C, Nagalla B, Vazir S, Bentley ME. Does maternal autonomy influence feeding practices and infant growth in rural India? Social science \& medicine. 2011; 73(3):447-55.

[19] Mashal T, Takano T, Nakamura K, Kizuki M, Hemat S, Watanabe M, et al. Factors associated with the health and nutritional status of children under 5 years of age in Afghanistan: family behaviour related to women and past experience of war-related hardships. BMC public health. 2008; 8:301.

[20] Begum S, Sen B. Maternal health, child well-being and chronic poverty: does women's agency matter? Bangladesh Development Studies. 2009; 32(4):69-93.

[21] Moestue H, Huttly S, Sarella L, Galab S. 'The bigger the better'-mothers' social networks and child nutrition in Andhra Pradesh. Public health nutrition. 2007; 10(11):1274-82.

[22] De Silva MJ, Harpham T. Maternal social capital and child nutritional status in four developing countries. Health \& place. 2007; 13(2):341-55.

[23] Allendorf K. Do Women's Land Rights Promote Empowerment and Child Health in Nepal? World development. 2007; 35(11):1975-88. 
[24] Wamani H, Tylleskar T, Åstrøm AN, Tumwine JK, Peterson S. Mothers' education but not fathers' education, household assets or land ownership is the best predictor of child health inequalities in rural Uganda. International journal for equity in health. 2004;3(1):9.

[25] Frost MB, Forste R, Haas DW. Maternal education and child nutritional status in Bolivia: finding the links. Social science \& medicine. 2005;60(2):395-407. 